\title{
PERANAN GURU PAK SEBAGAI KOMUNIKATOR DALAM MENINGKATKAN KOMUNIKASI YANG EFEKTIF KEPADA SISWA KELAS XI SMK NEGERI I SIATAS BARITA TAHUN PEMBELAJARAN 2017/2018
}

\author{
Tianggur Medi Napitupulu \\ Institut Agama Kristen Negeri Tarutung \\ Email: tianggurnapitupulu74@yahoo.co.id
}

\begin{abstract}
Abstrak-Penelitian ini bertujuan untuk mengetahui Peranan Guru PAK dalam meningkatkan komunikasi yang efektif kepada siswa kelas XI SMK negeri I Siatas Barita Tahun Pembelajaran 2017/2018. Instrumen yang digunakan untuk mengumpulkan dalam penelitian ini adalah angket. Data tersebut diolah sesuai dengan kaidah teknik deskriftif. Seluruh siswa Kelas XI sebanyak 280 orang menjadi objek penelitian, dengan sampel $15 \%$ dari jumlah populasi yang dilakukan secara acak atau random sehingga didapat sampelnya sebanyak 42 orang dan sebagai bahan uji coba angket 10 orang diluar responden. Instrumen yang digunakan angket tertutup yang terdiri dari 25 item yang disusun sendiri oleh penulis, validitas angket diuji dengan menggunakan rumus Product Moment Pearson diperoleh $\left.r_{\text {hitung }}>r_{\text {tabel }}(0,689-0,941)>0,632\right)$ sehingga instrumen valid dan reliabilitas diuji dengan menggunakan rumus Alpha. Uji coba menyatakan angket valid dan reliabel dengan tingkat reliabilitasnya 0, 995 terdapat pada korelasi tinggi. Berdasarkan analisis data diperolah hasil bahwa "Peranan Guru PAK sebagai Komunikator dalam Meningkatkan Komunikasi yang Efektifkepada siswa kelas XI SMK Negeri I Siatas Barita Tahun Pembelajaran 2017/2018 berada pada kategori baik dengan nilai 3,29, dengan demikian hipotesa penelitian diterima.
\end{abstract}

Kata Kunci: guru PAK, komunikasi yang efektif

\section{PENDAHULUAN}

Perkembangan ilmu pengetahuan dan teknologi (IPTEK) dewasa ini semakin terasa keberadaannya di segala aspek kehidupan. Kemajuan demi kemajuan telah dicapai melalui ilmu pengetahuan dan teknologi yang serba canggih. Sejalan dengan kemajuan tersebut mempengaruhi kehidupan masyarakat terutama para siswa, baik dari sisi positif maupun dari sisi negatif. Sebagaimana kita lihat sekarang ini siswa dituntut untuk aktif dalam proses belajar mengajar supaya dapat mengikuti keadaan zaman yang semakin berkembang.

Menurut pengamatan penulis, di SMK Negeri I Siatas Barita kelas XI dalam hal proses belajar mengajar bahwa keaktifan siswa semakin melemah dalam berkomunikasi, komunikasi yang terjadi lebih cenderung komunikasi satu arahdi mana guru yang lebih berperan dalam kegiatan belajar mengajar. Dalam kegiatan proses belajar mengajar siswa pada umumnya hanya datang, duduk, diam dan mendengar tanpa adanya suatu interaksi yang diharapkan dari siswa.

Pembelajaran sebagai proses interaksi berarti menempatkan guru bukan hanya sebagai sumber belajar akan tetapi juga sebagai pengatur interaksi mereka. Guru perlu mengarahkan agar siswa dapat mengembangkan kemampuan berpikirnya melalui interaksi mereka. Kemampuan guru untuk mengatur berkomunikasi dengan siswa dalam proses belajar mengajar bukan pekerjaan yang mudah. Sering guru terjebak oleh kondisi yang tidak tepat, sehingga membuat terhambatnya komunikasi.

Seorang guru Pendidikan Agama Kristen harus professional dalam profesinya 
agar mereka mampu menciptakan komunikasi yang efektif. Untuk mencapai hasil tersebut maka guru harus dapat mengenal siswanya dengan segala tenaga dan pikirannya demi meningkatkan mutu pendidikan siswa. Siswa sangat membutuhkan peranan guru sebagai komunikator dalam menciptakan komunikasi yang efektif.

\section{METODE}

Sesuai dengan judul penelitian ini, maka yang menjadi lokasi penelitian adalah di SMK Negeri 1 Siatas Barita yang beralamat di Simorangkir, Kecamatan Siatas Barita, Kabupaten Tapanuli Utara. Adapun alasan penulis memilih lokasi tersebut adalah karena penulis ingin mengetahui sejauh mana peranan guru PAK sebagai komunikator dalam menciptakan komunikasi yang efektif kepada siswa di sekolah tersebut.

Waktu penelitian dilaksanakan pada bulan Juli - Agustus 2018. Waktu yang ditentukan akan disesuaikan dengan situasi yang ada.

Populasi adalah suatu kegiatan penelitian yang berhadapan dengan objek yang diteliti yang berupa individu yang dapat dijadikan sebagai subjek atau objek penelitian oleh seorang peneliti.

Arikunto (1989 : 115) mengatakan "Populasi adalah keseluruhan objek yang diteliti yang di dalamnya terdapat subjek yang dapat dijadikan sumber data bagi peneliti".

Dari pendapat di atas maka penulis mengambil suatu kesimpulan bahwa populasi adalah keseluruhan objek yang di dalamnya terdapat subjek yang akan dijadikan sebagai sumber data bagi penelitian yang akan dilakukan baik itu mahkluk hidup maupun gejala-gejala atau peristiwa tertentu.

Yang menjadi populasi dalam penelitian ini adalah seluruh siswa kelas XI yang beragama Kristen Protestan di SMK Negeri 1 Siatas Barita Tahun Pembelajaran 2017/2018.

Mengingat banyaknya ukuran populasi tersebut, ada kaitannya keterbatasan waktu dan kemampuan peneliti, maka peneliti mengambil sampel yang dianggap representatif untuk mewakili populasi.

Arikunto (1989 : 120) mengatakan "Apabila subjeknya kurang dari 100 lebih baik diambil semua sehingga penelitiannya merupakan penelitian populasi, dan selanjutnya jika jumlahnya lebih besar daripada 100 maka dapat diambil antara 10$15 \%$ atau $20-25 \%$ atau lebih".

Sesuai dengan pendapat di atas maka penulis mengambil sampel $15 \%$ dari jumlah populasi yaitu $15 \%$ X 280 orang $=42$ orang.

Untuk melihat bagaimana peranan guru PAK sebagai komunikator dalam menciptakan komunikasi yang efektif digunakan angket sebanyak 25 butir yang terdiri dari 4 opsi, yaitu: a. Selalu, b, Sering, c. Kadang-kadang, d . Tidak pernah.

Di dalam pemberian bobot alternatif jawaban, peneliti menggunakan ketentuan yang dikemukakan oleh Nasution (1987 : 17) yaitu : Untuk angket dengan pertanyaan positif :

- Jawaban "a" diberi bobot 4 (selalu)

- Jawaban "b" diberi bobot 3 (sering)

- Jawaban "c" diberi bobot 2 (kadangkadang)

- Jawaban "d' diberi bobot 1 (tidak pernah)

Dalam penelitian ini angket menggunakan pertanyaan positif. Untuk memperoleh instrument yang sah dilakukan uji coba prosedur di mana yang dilakukan adalah penyusunan instrument, penentuan responden, pelaksanaan uji coba dan analisis instrument. Untuk mengetahui dan memiliki butir-butir instrument yang valid dan 
reliabel, dilakukan uji coba instrument. Uji coba angket dilakukan kepada 10 orang siswa kelas XI SMK Negeri 1 Siatas Barita yang tidak menjadi responden penelitian yang ditentukan oleh peneliti secara acak.

Uji validitas dilakukan untuk mengetahui tingkat ketepatan instrument digunakan. Setelah data hasil uji coba terkumpul, kemudian dianalisis dengan mencari harga koefisien korelasi $\left(\mathrm{r}_{\mathrm{xy}}\right)$ dengan menggunakan rumus Product Moment Person (Arikunto 2007 : 327)

$$
\begin{aligned}
& \mathrm{r}_{\mathrm{xy}}= \\
& \frac{N \cdot \sum x y-\left(\sum x\right)\left(\sum y\right)}{\left.\sqrt{\left(\left(N \cdot \sum x^{2}\right) \cdot\left(\sum x\right)^{2}\right\}}\right\}\left(N \cdot \sum y^{2}\right) \cdot\left(\sum y\right)}
\end{aligned}
$$

Dimana :

$\sum x=$ Jumlah skor variabel $\mathrm{x}$

$\sum y=$ Jumlah skor variabel $\mathrm{y}$

$\sum x y=$ Jumlah perkalian $\mathrm{xy}$

$\mathrm{N}=$ Populasi

Uji reliabilitas instrument merupakan pengujian tingkat konsisten angket itu sendiri. Instrument yang baik harus konsisten dengan butir yang diukur. Keberadaan instrument dalam penelitian ini dianalis dengan rumus formula Alpha oleh Arikunto (2007 : 180), yaitu :

$$
\mathrm{r}_{11}=\left[\frac{K}{K-1}\right]\left[1-\frac{\sum \sigma b^{2}}{1 \sigma \tau^{2}}\right]
$$

dimana :

$\mathrm{r}_{11}=$ Reliabilitas instrument

$\mathrm{k}=$ Jumlah item

$\Sigma \sigma \mathrm{t}^{2}=$ Jumlah variabel item soal

$\sigma \mathrm{t} \quad=$ Jumlah variebel total

Harga $r_{11}$ dikonsultasikan dengan cara mengartikan indeks korelasi hitung dengan interprestasi sederhana yang dibuat oleh Arikunto (1989:167) yaitu :

$0,800-1,00 \quad$ sangat tinggi

$0,600-0,799$ tinggi
$0,400-0,599$ cukup

$0,200-0,399$ rendah

$<0,200$

sangat rendah

Dalam menganalisa data yang diperoleh dari hasil penelitian ini dilakukan dengan cara :

1. Mentabulasikan jawaban dari responden

2. Memberi pembobotan pada setiap jawaban dari responden

3. Mengelola data yaitu dengan mencari nilai ) $: \bar{X}$ masing-masing item dari dan nilai ) $: \bar{X}$ keseluruhan Peranan Guru PAK sebagai komunikator dalam menciptakan komunikasi yang efektif dengan rumus yang dikutip Suryadi $(1986: 80)$ :

$$
\bar{X}=\frac{(f a x 4)+(f b x 3)+(f c x 2)+(f d x 1)}{N}
$$

Dimana :

$\bar{X}$ =bobot jawaban rata-rata

$\mathrm{N}=$ jawaban responden

$\mathrm{f}^{\mathrm{a}}=$ frekuensi jawaban a

$\mathrm{f}^{\mathrm{b}}=$ frekuensi jawaban $\mathrm{b}$

$\mathrm{f}^{\mathfrak{c}}=$ frekuensi jawaban $\mathrm{c}$

$\mathrm{f}^{\mathrm{d}}=$ frekuensi jawaban $\mathrm{d}$

Untuk menganalisa data dilakukan dengan mengikuti kategori yang dikemukakan Nurkanca (1986: 81) sebagai berikut :

3,60 - 4,00 kategori baik sekali

2,60 - 3,59 kategori baik

1,60 - 2,59 kategori kurang

1,00 - 1,59 kategori gagal

Kriteria penerimaan / penolakan hipotesa

Jika nilai $\bar{X}$ berada pada interval 1,00-2.59 maka hipotesa ditolak

Jika nilai $\bar{X}$ berada pada interval 2,60-4,00 maka hipotesa diterima

$$
\begin{array}{ll}
2,60-3,59 & \text { kategori baik } \\
1,60-2,59 & \text { kategori kurang } \\
1,00-1,59 & \text { kategori gagal }
\end{array}
$$

\section{PEMBAHASAN}

Proses belajar mengajar merupakan proses komunikasi yang dilakukan oleh guru 
PAK dan siswa di dalam situasi tertentu. Mengajar atau lebih spesifik lagi melaksanakan proses belajar mengajar bukanlah suatu pekerjaan yang mudah dan dapat terjadi begitu saja tanpa direncanakan sebelumnya, akan tetapi mengajar itu merupakan suatu kegiatan yang semestinya direncanakan dan didesain sedemikian rupa mengikuti langkah-langkah dan prosedur tertentu.

Dalam proses belajar mengajar diperlukan suatu komunikasi dua arah yang baik antara siswa dan guru karena dengan demikian akan tercipta komunikasi yang efektif.

Untuk itu di dalam proses belajar mengajar guru harus memperhatikan bahan yang hendak disampaikan kepada siswa, apakah bahan yang disampaikan dapat diterima dan dipahami siswanya dengan baik. Ini merupakan masalah yang sangat sulit dirasakan guru. Kesulitan ini dikarenakan siswa bukan hanya sebagai individu dengan segala keunikannya, tetapi mereka juga sebagai mahluk sosial dengan latar belakang yang berlainan. Dalam proses belajar mengajar guru juga perlu memperhatikan situasi dan lingkungan dimana ia mengajar. Untuk itu guru harus dapat mengerti tingkat kesiapan siswa ketika mendengarkan pesan yang disampaikan.

Di dalam proses belajar mengajar guru harus dapat memberi penilaian atas kemajuan siswa. Ketika guru memberikan tugas atau melakuan ujian kepada siswa ada baiknya guru memberikan penilaian kepada siswa supaya mereka lebih semangat dalam proses belajar mengajar dan tidak pasif terhadapa pelajaran PAK.

Didalam berkomunikasi juga diperlukan media yang bervariasi supaya terciptanya kelancaran komunikasi dengan baik. Dengan adanya metode belajar yang dapat merangsang terciptanya komunikasi yang efektif seperti penggunaan media gambar, internet akan dapat membantu siswa untuk lebih aktif dalam kegiatan belajar mengajar

Di dalam proses belajar mengajar, guru tidak boleh membedakan siswa, baik dari segi fisik, psikologis maupun material yang akan mengakibatkan siswa jadi merasa diasingkan. Komunikasi akan tercipta dengan baik apabila ada kerja sama yang baik antara guru dan siswa. Untuk itu, guru harus memberi penilaian atas kemajuan siswa dan memberi perhatian serta waktunya kepada siswa. Dengan demikian, akan terciptanya komunikasi yang efektif di dalam proses belajar mengajar.

Komunikasi yang efektif akan tercipta apabila guru sebagai komunikator dapat menyampaikan bahan pelajaran yang diberikan kepada siswa. Untuk itu, guru harus dapat menggunakan variasi belajar seperti halnya di dalam proses belajar mengajar guru harus dapat melibatkan siswa. Hal ini dimaksudkan agar tidak menimbulkan kebosanan, kejenuhan serta untuk menghidupkan suasana kelas demi keberhasilan siswa dalam mencapai tujuan. Karena proses belajar mengajar akan berhasil bila hasilnya mampu membawa perubahan dalam pengetahuan, pemahaman, keterampilan dan nilai sikap dalam diri anak didik.

Sebagai seorang pengajar, guru PAK sebagai komunikator harus menyadari bahwa dia harus mempunyai peranan penting dalam menciptakan komunikasi yang efektif. Guru harus dapat mengajar siswa dengan baik. Apabila guru PAK dapat melakukan perannya dengan baik maka akan dapat menciptakan komunikasi yang efektif kepada siswa.

Soekanto (1990:269) mengatakan bahwa peranan mencakup 3 hal yaitu:

1. Peranan meliputi norma-norma yang dihubungkan dengan posisi atau tempat seseorang dalam masyarakat. Peranan dalam arti ini merupakan rangkaian peraturan-peraturan yang membimbing 
seseorang dalam kehidupan kemasyarakatan.

2. Peranan adalah suatu konsep tentang apa yang dapat dilakukan oleh individu dalam masyarakat sebagai organisasi.

3. Peranan juga dapat dikatakan sebagai perilaku individu yang penting bagi struktur sosial masyarakat.

Peranan merupakan suatu norma yang dilakukan oleh individu yang bersangkutan. Untuk itu seorang guru PAK mempunyai banyak peranan penting dalam mendidik siswa ke arah yang lebih baik supaya siswa berguna bagi kehidupan bermasyarakat.

Gunarsa (2003:101) mengemukakan bahwa peranan itu adalah:

1. Suatu peran adalah sekelompok normanorma dan harapan mengenai tingkah laku seseorang.

2. Norma-norma dan harapan yang dimiliki oleh orang-orang di lingkungan dekat dengan individu itu.

3. Norma-norma dan harapan tersebut memang diketahui dan disadari oleh individu yang bersangkutan.

Dari pendapat di atas, maka penulis dapat mengartikan bahwa peranan itu adalah keikutsertaan di dalam suatu peristiwa atau kegiatan dalam kehidupan sosial yang ditunjukkan dengan suatu tindakan atau perbuatan yang bermanfaat bagi pribadi sendiri maupun orang lain dan juga dilakukan berdasarkan ketentuan atau norma yang berlaku. Peranan dapat juga diartikan sebagai tugas dan tanggungjawab seseorang di dalam kehidupan bermasyarakat.

Demikian juga halnya dengan peranan guru PAK sebagai komunikator yang sangat dibutuhkan dalam menciptakan komunikasi yang efektif supaya proses belajar mengajar dapat tercipta dengan baik. Dengan demikian siswa diharapkan mampu hidup dan mengembangkan dirinya di tengah masyarakat dengan berbekal pengetahuan dan pengalaman yang sudah melekat pada dirinya.
Sehubungan dengan fungsinya sebagai "Pengajar", "Pendidik" dan "Pembimbing", maka diperlukan adanya berbagai peranan pada diri guru. Peranan guru ini akan senantiasa menggambarkan pada tingkah laku yang diharapkan dalam berbagai interaksinya baik dengan siswa, sesama guru maupun dengan sifat lainnya. Dengan berbagai kegiatan interaksi belajar mengajar dapat dipandang sebagai sentral bagi perannya.

Sumiyatiningsih (2006 : 40-43) mengemukakan beberapa peranan pendidik dalam mengajar yaitu:

1. Pendidik sebagai sahabat

Sahabat yang dimaksudkan bukan tentang relasi ataupun teman sebaya, melainkan lebih tentang hubungan pribadi yang mengasihi, memelihara, menolong dan mengembangkan sehingga keduanya dapat bertumbuh bersama.

2. Pendidik yang penerjemah

Sebagai pendidik kita lebih baik berperan sebagai penerjemah, bukan hanya sekedar transittor. Transmitter adalah sebuah alat yang dipakai pada televise atau radio dan berfungsi untuk mengirimkan berita satu arah. Dalam pengalaman di kelas, banyak peserta didik yang mengalihkan "chanel" atau "gelombang", membesarkan atau mengecilkan suara pendidik yang berperan sebagai transmitor.

3. Pendidik sebagai jenis kurikulum

Sebagian orang menganggap bahwa tugas menulis kurikulum terlalu berat karena kebanyakan pendidik merasa tidak memiliki kualifikasi sebagai penulis kurikulum. Pendidik dapat menggunakan bahan ajar atau buku teks sebagai panduan yang sering kali dilengkapi dengan buku guru untuk mengajar atau sumber-sumber lain yanbg dipandang perlu.

4. Pendidik sebagai seorang pelajar/murid 
Seorang pendidik seharusnya tidak berhenti belajar, dia harus terus-menerus memperdalam atau mencari informasi baru mengenai keberadaan peserta didik yang diajar, mengenai cara atau model pengajaran yang menarik dan relevan serta mengenai konsep-konsep Alkitabiah maupun teologis yang akan diajarkan.

Di dalam proses belajar mengajar, guru bukan hanya berperan sebagai pengajar. Guru terpanggil memainkan sejumlah peran individual dan sosial, guru tidak hanya sebatas menjelaskan bahan pelajaran tetapi harus dapat membantu siswa untuk terampil dalam berbagai bidang terutama dalam hal berkomunikasi.

Menurut Sidjabat (1993:101), bahwa ada dua belas peranan guru PAK, yaitu: sebagai pendidik, pengajar dan pembelajaran, pelatih, fasilitator, motivator, pemimpin, komunikator, agen sosialisasi, pembimbing, pemberita Injil,iman dan Nabi dan Teolog.

Dari pandangan di atas, dapat kita ketahui bahwa seorang guru PAK tidaklah mudah, karena karena apa yang dilakukan seorang guru PAK harus mampu menjadikan siswanya menjadi manusia yang lebih baik. Guru PAK harus dapat melakukan peranannya dengan baik, supaya siswanya dapat berhasil. Untuk itu, guru PAK harus melakukan komunikasi yang baik dengan siswanya supaya proses belajar mengajarnya tercapai dengan baik.

Di samping berperan sebagai pendidik dan pengajar, guru PAK juga harus berperan sebagai komunikator, karena dengan terciptanya komunikasi antara guru dan siswa, maka suasana proses belajar mengajar akan terlaksana dengan baik.

Sidjabat (1993:117-120) mengatakan sebagai komunikator guru harus:

1. Memberi penilaian atas kemajuan peserta didik

Dengan bijaksana, ia menyampaikan imformasi yang berguna bagi mereka. Ia menjaga dirinya agar tetap dapat menyampaikan kritikan dan informasi secara tepat dan jujur. Ia juga harus mengembangkan kemampuannya untuk mengemukakan kesan dan pesan yang membangunkan semangat. Jika tidak demikian, peserta didk dapat menyimpan akar pahit ataupun kesalahan di dalam dirinya, yang akan menghambat kemajuan belajar.

Pentingnya komunikasi yang membangun itu dapat kita pelajari dari nasehat Rasul Paulus kepada jemaat di Efesus. " Janganlah ada perkataan kotor keluar dari mulutmu, tetapi pakailah perkataan yang baik untuk membangun di mana perlu supaya mereka yang mendengarnya beroleh kasih karunia.

2. Sebagai komentator

Dalam hal ini, guru harus mengembangkan kemampuan dalam melihat secara objektif kekurangan dan kelebihan peserta didiknya. Ia harus terus menerus belajar membedakan antara kekurangan pribadi, misalnya bentuk fisik dan latar belakang keluarganya dan kekurangan dalam kegiatan studi peserta didiknya. Ia harus dapat membedakan apakah yang sedang dikritiknya itu menyangkut masalah pribadi atau masalah pekerjaan, berkaitan dengan tugas studinya dan pengembangan pendapat. Melalui kemampuan seorang guru sebagai komentator dan komunikator itulah, peserta didik memperoleh latihan untuk tahu membedakan persoalan-persoalan yang menyangkut pribadi dengan masalahmasalah yang berkaitan dengan tingkah laku. Kemampuan itu begitu penting bagi masa depan mereka.

3. Sebagai mediator

Ia menjadi mediator di antara peserta didik dengan bahan pengajaran dan di antara sesama peserta didik. Tugas gurulah untuk membuat peserta didik 
mencintai dan tepatnya bersahabat dengan bahan pengajaran dengan bidang studi yang ditekuninya. Kalau di antara guru dengan bahan pengajaran terjadi "permusuhan" karena merasa sukar asing atau tidak relevan. Misalnya hasil belajarpun menjadi tidak memuaskan. Untuk itu, cara guru mengajar harus perlahan, bertolak dari hal-hal sederhana dan menyenangkan, kemudian berlanjut ke dalam hal-hal yang lebih mendalam.

4. Memberi perhatian dan waktunya untuk mewujudkan perdamaian

Seorang guru PAK harus berdoa kepada Tuhan untuk terjadinya perkara di antara peserta didik. Yesus Kristus menegaskan bahwa berbahagialah orang yang membawa atau mewujudkan damai karena mereka di sebut anak-anak Allah (Mat 5:9). Dengan demikian, melalui keseluruhan kegiatan belajar dan mengajar, guru juga harus berupaya membimbing peserta didik supaya memberi diri kepada Allah dan mengalami pendamaian dengan Allah, dengan dirinya, serta dengan sesamanya (bdk. 2 Kor 5:8-9). Jadi, perkataan, sikap dan perbuatan guru itu sendiri dituntut untuk senantiasa menunjang tujuan tersebut.

5. Mengutamakan pemberian berita dari segi kebutuhan pendengarnya.

Begitu pula dengan guru, ia harus menyampaikan pengajaran sesuai dengan kebutuhan peserta didiknya. Harus selalu ada yang sama antar guru dan muridnya supaya berlangsung komunikasi. Oleh karena itu, ia perlu mengetahui dimana peserta didiknya berada, baik secara rohani, intelek, moral, maupun secara fisik. Misalnya, mungkin saja murid dalam kelelahan fisik sehingga tampak lesu dan tidak bersemangat belajar. Mungkin saja murid melakukan pelanggaran moral, sehingga dilanda rasa bersalah dan responnya terhadap Firman
Tuhan yang diajarkan guru PAK tidak positif.

6. Mengerti tingkat kesiapan anak didiknya ketika mendengarkan pesan yang disampaikan

Sebuah pesan baik dapat ditanggap negatif oleh anak didik karena kesiapannnya masih rendah. Sebagai komunikator guru terpanggil untuk menggunakan kata-kata yang jelas, tepat, menggembirakan dan sesuai dengan peserta didik. Kata-kata atau terminologi yang diucapkan itu haruslah sedemikian jelas, sehingga tidak lagi menimbulkan penafsiran yang salah. Caranya mengkomunikasikan secara kineskesik, termasuk melalui tatapan muka serta gerakan tangan dan kaki, harus mendapat perhatian untuk menghindari penafsiran yang keliru.

Sesuai dengan pendangan diatas, maka penulis menyimpulkan bahwa sebagai komunikator guru PAK harus mampu mengenal siswa dan melakukan komunikasi dengan baik. Guru PAK harus mampu melakukan kegiatan belajar mengajar dengan baik supaya tercipta komunikasi yang efektif.

Effendy (2007:38-39), mengatakan ada dua faktor penting pada diri komunikator bila ia melancarkan komunikasi, yaitu :

1. Daya tarik sumber

Seorang komunikator akan berhasil didalam komunikasi, akan mampu mengubah sikap, opini dan perilaku komunikan melalui mekanisme dan daya tarik jika pihak komunikan merasa bahwa komunikator ikut serta dengannya. Dengan lain perkataannya, komunikan merasa ada kesamaan antara komunikator dengannnya sehingga komunikan bersedia taat pada isi pesan yang dilancarkan oleh komunikator.

2. Kreadibilitas sumber 
Faktor kedua yang bisa menyebabkan komunikasi berhasil ialah kepercayaan komunikan pada komunikator. Kepercayaan ini banyak bersangkutan dengan profesi atau keahlian yang dimiliki sebagai komunikator.

Berdasarkan kedua faktor itu, maka seorang komunikator sering menghadapi komunikan harus bersifat empatik, yaitu kemampuan seseorang untuk memproyeksikan dirinya kepada peranan orang lain. Dengan kata lain perkataan dapat merasakan apa yang dirasakan orang lain.

Kristianto (2006:23) mengatakan, beberapa panduan untuk melancarkan komunikasi yang jelas sehingga mempermudah untuk mencapai tujuan PAK adalah :

1. Hindari kata-kata etnis yang sulit jika ada kata-kata yang mudah

2. Perjelas kata sederhana sehingga menghindari kesalahpahaman

3. Tenangkan pikiran supaya pesan dapat diterima

4. Gunakan pendekatan dengan panca indra jika ingin memperjelas ajaran

5. Pertanyaan- pertanyaan dapat menjadi alat yang efektif jika pengajar mengharapkan pengertian yang lebih dalam

6. Pertanyaan-pertanyaan diperlukan untuk membangkitkan ide-ide dan membantu para murid menerapkan pelajaran dalam hidupnya

7. Utamakan untuk memperoleh umpan balik dari pada murid

Berdasarkan kutipan di atas, maka penulis menyimpulkan bahwa seorang guru PAK sebagai komunikator mempergunakan bahasa yang baik dan benar dalam berkomunikasi harus memilki pikiran yang tenang dalam menyampaikan pesan, melakukan pendekatan dan membuat pertanyaan yang dapat merespon siswa.

Perbuatan mengajar tidak terlepas dari aktivitas belajar. Dan di dalam aktivitas harus terjalin aktivitas komunikasi antara guru dengan siswa. Untuk itu, guru harus dapat melakukan komunikasi yang efektif di dalam kelas.

Shannon dan Weaver yang dikutip oleh Cangara (2005:19) mengatakan: "Komunikasi adalah bentuk interaksi manusia yang saling pengaruh mempengaruhi satu sama lainnya".

Komunikasi adalah suatu proses interaksi antara suatu individu dengan individu yang lain yang saling mempengaruhi.

Rakhmat (2005:9) mengatakan: "Komunikasi adalah peristiwa sosial, peristiwa yang terjadi ketika manusia berinteraksi dengan manusia lain".

Komunikasi adalah suatu kegiatan antara individu yang satu dengan individu yang lain dalam hal penyampaian pendapat.

Wursanto (2001:31) mengatakan: Komunikasi adalah proses kegiatan pengoperan/ penyampaian warta/berita/ imformasi yang mengandung arti dari satu pihak (seseorang atau tempat) kepada pihak (seseorang atau tempat) lain, dalam usaha mendapatkan saling pengertian.

Komunikasi adalah suatu proses di mana adanya pertukaran pikiran antara suatu individu dengan individu yang lain yang menciptakan terjadinya hubungan sosial dalam masyarakat.

Mulyana (2002:41) mengatakan bahwa Komunikasi adalah suatu topik yang amat sering diperbincangkan, bukan hanya dikalangan ilmuan komunikasi, melainkan juga di kalangan awam, sehingga kata komunikasi itu sendiri memiliki terlalu banyak arti yang berlainan.

Dari penjelasan di atas, maka penulis mengambil kesimpulan bahwa komunikasi adalah suatu cara untuk menyampaikan informasi atau pesan dari komunikator (pembicara) kepada komunikan (pendengar) dalam hal bertukar pikiran. Jadi di dalam proses belajar mengajar sering terjadi 
komunikasi antara guru dan siswa dalam menyampaikan materi pelajaran. Sebagaimana Tuhan Yesus dalam mengajar dengan orang banyak, Dia juga melakukan komunikasi.

Belajar mengajar adalah proses sebuah interaksi. Untuk mencapai interaksi belajar mengajar sudah barang tentu perluadanya komunikasi yang jelas antara guru (pengajar) dengan siswa (pelajar), sehingga terpadunya dua kegiatan, yakni kegiatan mengajar (usaha guru) dan kegiatan belajar (tugas siswa) yang berdaya guna dalam mencapai tujuan pengajaran. Seringkali kita jumpai kegagalan pengajaran disebabkan lemahnya sistem komunikasi yang efektif dalam proses belajar mengajar. Untuk itulah guru perlu mengembangkan pola / bentuk komunikasi yang efektif dalam proses belajar mengajar.

Siahaan (1991:19-22) mengatakan bahwa ada beberapa bentuk komunikasi, yaitu:

1. Komunikasi antar pribadi

Komunikasi ini terjalin antar dua pribadi, bersifat langsung dan sering dalam bentuk percakapan. Komunikasi ini bersifat dua arah. Komunikasi ini dikatakan efektif bila akhirnya menghasilkan perubahan sikap pada orang yang terlihat dalam komunikasi itu. Komunikasi ini juga dikatakan efektif bila komunikator dan komunikan seimbang dan mempunyai kebersamaan, persoalan yang sama, perjuangan yang sama dan tujuan yang sama.

2. Komunikasi antar kelompok

Komunikasi antar kelompok akan berlaku antara seorang komunikator dengan jumlah komunikan yang berkumpul bersama-sama.

3. Komunikasi massa

Secara umum komunikasi massa terdiri dari empat macam, yaitu : pers, radio, film, dan televisi.
Dari kutipan di atas penulis dapat menyimpulkan bahwa bentuk komunikasi itu terdiri dari komunikasi antar pribadi, komunikasi antar kelompok dan komunikasi massa, di mana ketiga komunikasi itu dapat digunakan dalam proses belajar mengajar PAK tapi harus disesuaikan dengan situasi dan kondisi materi pelajaran.

Menurut Effendy (2007:7), bentuk komunikasi yaitu:

1. Komunikasi persona (personal communication)

a. Komunikasi intra persona (intrapersonal communication)

b. Komunikasi antar persona (interpersonal communication)

2. Komunikasi kelompok (group communication)

a. Komunikasi kelompok kecil (small group communication)

1. Ceramah (lecture)

2. Diskusi panel (panel discussion)

3. Simposium (symposium)

4. Forum

5. Seminar

6. Curah saran (brainstorming)

7. Dan lain-lain

b. Komunikasi kelompok besar (large group communication/ public speaking)

3. Komunikasi

massa

(mass communication)
a. Pers
b. Radio
c. Televisi
d. Film
e. Dan lain-lain

4. Komunikasi

medio

(medio communication)
a. Surat
b. Telepon
c. Pamflet
d. Poster
e. Spanduk
f. Dan lain-lain 
Dari kutipan di atas penulis menyimpulkan bahwa bentuk komunikasi itu terdiri dari komunikasi persona, komunikasi kelompok, komunikasi massa dan komunikasi medio. Sebagai mana yang kita lihat dalam proses belajar mengajar komunikasi yang dilakukan komunikasi yang sering dilakukan adalah komunikasi intrapersona di mana guru PAK melakukan pengajaran dengan langsung dengan siswa.

Segala sesuatu yang kita lakukan pasti memiliki tujuan. Demikian halnya dalam apabila kita sedang berkomunikasi dengan seseorang, kita juga memiliki tujuan yang kita harapkan.

Menurut Effendy (2007: 8) tujuan komunikasi ada 4, yaitu:

1. Perubahan sikap

Kegiatan memberikan berbagai imformasi pada masyarakat dengan tujuan supaya masyarakat akan berubah sikapnya.

2. Perubahan pendapat

Memberikan berbagai imformasi pada masyarakat dengan tujuan akhirnya supaya masyarakat mau berubah pendapat dan persepsinya terhadap tujuan imformasi itu disampaikan.

3. Perubahan perilaku

Kegiatan memberikan berbagai imformasi kepada masyarakat dengan tujuan supaya masyarakat akan berubah perilakunya.

4. Perubahan sosial

Memberikan berbagai imformasi pada masyarakat dengan tujuan akhirnya supaya masyarakat mau mendukung dan ikut serta terhadap tujuan imformasi yang disampaikan.

Komunikasi bertujuan untuk mengubah perilaku dan sikap seseorang dalam membangun kesatuan demi tercapainya tujuan yang hendak dicapai sehingga di dalam menjalin hubungan antara komunikator dengan komunikan diperlukan komunikasi.
Siahaan (1991:4) mengatakan bahwa komunikasi bertujuan merubah tingkah laku seseorang, merubah pola pikir atau sikap orang lain (komunikan) untuk dapat membangun kebersamaan, mencapai ide yang sama demi tujuan bersama.

Dari kutipan di atas maka penulis mengambil kesimpulan bahwa kalau kita melakukan komunikasi pasti kita mempunyai tujuan yang diharapkan sebagaimana seorang guru PAK sebagai komunikator dalam proses belajar mengajar, dia berperan sebagai komunikator dengan tujuan supaya siswa dapat mendapat pengetahuan yang lebih baik.

Hal ini juga dapat kita lihat sebagaimana Yesus dalam melakukan komunikasi. Misalnya, ketika Yesus berbicara dengan murid-muridnya dalam hal membayar pajak. Di mana Yesus menyuruh kita untuk membayar pajak kepada pemerintah sebagai kewajiban kita (Mar. 12: 13-17). Yesus juga melakukan komunikasi dengan tujuan supaya sebelum menuduh seseorang berbuat dosa, kita harus memperhatikan diri kita sendiri,di mana adanya perempuan berzinah yang ingin dilempari orang-orang Farisi, tetapi Yesus berkata: " Barang siapa di antara kamu tidak berdosa, hendaklah ia yang pertama melempar batu kepada perempuan itu (Yoh. 8:10)". Mendengar perkataan Yesus maka orang-orang Farisi tidak jadi melempari perempuan itu.

Komunikasi adalah kunci keberhasilan berinteraksi dalam menjalin hubungan sosial. Untuk itu, sebagai mahkluk sosial kita perlu melakukan komunikasi. Terutama dalam hal proses belajar mengajar pada umumnya komunikasi yang dilakukan adalah komunikasi tatap muka antara guru dengan siswa.

Menurut Lestari dan Maliki (2009:9), ciri-ciri komunikasi face to face (tatap muka) yaitu:

1. Arus pesan yang cenderung dua arah 
2. Konteks komunikasinya tatap muka

3. Tingkat umpan balik yang terjalin tinggi

4. Kemampuan mengatasi tingkat selektifitas terutama tinggi

5. Kecepatan jangkauan terhadap audiens yang besar relative tinggi.

Dari kutipan di atas, maka penulis menyimpulakan bahwa ciri-ciri komunikasi adalah adanya pesan, konteks, umpan balik. Hal ini dapat kita lihat sebagaimana terjadi dalam proses belajar mengajar oleh guru kepada siswa

Siahaan (1991:19), mengatakan bahwa ciri khas komunikasi bersifat dua arah atau timbal balik yang biasa disebut $t w o$ way traffic communication. Komunikator dan komunikan saling bertukar fungsi. Namun harus diingat bahwa yang memulai percakapan itulah komunikator pertama dan komunikator utama. Komunikator utamalah yang mempunyai tujuan tertentu melalui pelaksanaan komunikasi tersebut.

Dari kutipan di atas, maka penulis menyimpulakan bahwa ciri-ciri komunikasi itu adalah bersifat dua arah dan adanya pertukaran pikiran antara komunikator dan komunikan. Hal ini dapat kita lihat di dalam proses belajar mengajar, di mana guru sebagai komunikator mengajak siswa dalam melakukan komunikasi demi terciptanya komunikasi yang efektif.

Dari kutipan di atas, maka penulis menyimpulkan bahwa komunikasi interpersonal itu komunikator dan komunikan berada pada jarak yang dekat sehingga umpan balik yang terjadi berlangsung secara spontan. Di dalam proses belajar mengajar komunikasi ini sangat bagus dilakukan karena apabila ada katakata yang tidak dimengerti oleh komunikan (siswa) bisa langsung ditanya pada komunikator (guru).

Mulyana (2007:83) mengatakan Ciriciri komunikasi publik adalah : terjadi di tempat umum (publik), misalnya di auditorium, kelas, tempat ibadah atau tempat lainnya yang dihadiri sejumlah besar orang; merupakan peristiwa sosial yang biasanya telah direncanakan alih-alih peristiwa relatif imformal yang tidak terstruktur, terdapat agenda; beberapa orang ditunjuk untuk menjalankan fungsi-fungsi khusus, seperti memperkenalkan pembicara, dan sebagainya; acara-acara lain mungkin direncanakan sebelum atau sesudah ceramah disampaikan pembicara.

Dari kutipan di atas penulis menyimpulkan bahwa komunikasi terjadi di tempat umum di mana adanya satu komunikator dan komunikan yang banyak, dan ini biasanya terjadi pada proses belajar mengajar, hanya saja umpan balik yang diberikan terbatas.

Tidak sedikit orang yang memandang tugas mengajar sebagai pekerjaan yang mudah. Bahkan, banyak orang yang mau bertugas sebagai pengajar. Tapi apabila kita merasakan, tugas mengajar tidaklah mudah. Karena kita harus mampu melakukan interaksi belajar mengajar supaya tercipta proses belajar mengajar dengan baik.

Sardiman (2009:2) mengatakan Interaksi belajar mengajar mengandung suatu arti adanya kegiatan interaksi dari tenaga pengajar yang melaksanakan tugas mengajar di satu pihak, dengan warga belajar (siswa, anak didik / subjek belajar) yang melaksanakan kegiatan belajar di pihak lain.

Djamarah (2000:11) mengatakan "Interaksi edukatif adalah hubungan dua arah antara guru dan anak didik dengan sejumlah norma sebagai medium untuk mencapai tujuan pendidik".

Dari pendapat di atas penulis menyimpulkan bahwa interaksi belajar mengajar adalah suatu proses kegiatan belajar mengajar di mana adanya hubungan timbal balik antara guru dan siswa.

Guru PAK berperan aktif dalam interaksi belajar mengajar, sebagaimana Yesus mengajar orang banyak. Contohnya 
dalam hal perumpamaan tentang dua orang anak (Mat 21: 28-32), Yesus melakukan interaksi dengan metode tanya jawab.

Di dalam interaksi belajar mengajar kita juga perlu memperhatikan ciri-ciri interaksi belajar mengajar.

Djamarah (2000:15) mengatakan ciriciri interaksi belajar mengajar yaitu :

1. Interaksi edukatif mempunyai tujuan

Tujuan dalam interaksi edukatif adalah untuk membantu anak didik dalam suatu perkembangan tertentu. Inilah yang dimaksud interaksi edukatif sadar akan tujuan, dengan menempatkan anak didik sebagai pusat perhatian, sedangkan unsur lainnya sebagai pengantar dan pendukung.

2. Mempunyai prosedur yang direncanakan untuk mencapai tujuan

Agar dapat mencapai tujuan secara optimal, maka dalam melakukan interaksi perlu ada prosedur atau langkah-langkah sistematik dan relevan. Untuk mencapai suatu tujuan pembelajaran yang satu dengan yang lain, mungkin akan membutuhkan prosedur dan desain yang berbeda-beda.

3. Interaksi edukatif ditandai dengan penggarapan materi khusus

Dalam hal materi harus di desain sedemikian rupa, sehingga cocok untuk mencapai tujuan. Dalam hal ini perlu memperhatikan komponen pengajaran yang lain. Materi harus sudah di desain dan disiapkan sebelum berlangsungnya interaksi edukatif.

4. Ditandai dengan aktifitas anak-anak Sebagai konsekuensi, bahwa anak didik merupakan sentral, maka aktifitas anak didik merupakan syarat mutlak bagi berlangsungnya interaksi edukatif. Aktifitas anak didik dalam hal ini baik secara fisik maupun mental aktif.

5. Guru berperan sebagai pembimbing Dalam perananya sebagai pembimbing, guru harus berusaha menghidupkan dan memberikan motivasi agar terjadi proses interaksi edukatif yang kondusif. Guru harus siap sebagai mediator dalam segala situasi proses interaksi edukatif, sehingga guru akan merupakan tokoh yang akan dilihat dan ditiru tingkah lakunya oleh anak didik.

6. Interaksi edukatif membutuhkan disiplin Disiplin dalam interaksi edukatif diartikan sebagai suatu pola tingkah laku yang diatur menurut ketentuan yang sudah ditaati dengan sadar oleh pihak guru maupun pihak anak didik.

7. Mempunyai batas waktu

Untuk mempunyai tujuan pembelajaran tertentu dalam sistem berkelas (kelompok anak didik), batas waktu menjadi salah satu ciri yang tidak bisa ditinggalkan. Setiap tujuan akan diberi waktu tertentu, kapan tujuan harus sudah tercapai.

8. Diakhiri dengan evaluasi

Dari seluruh kegiatan tersebut, masalah evaluasi merupakan bagian penting yang tidak bisa diabaikan. Evaluasi harus dilakukan oleh guru untuk mengetahui tercapai atau tidak tujuan pengajaran yang telah ditentukan.

Sesuai dengan kutipan di atas, maka interaksi belajar mengajar harus memiliki tujuan, adanya prosedur, memiliki materi, adanya aktivitas peserta didik, adanya disiplin, harus disesuaikan dengan batas waktu dan melakukan evaluasi. Didalam interaksi belajar mengajar, guru PAK harus memenuhi ciri-ciri interaksi dalam mengajar supaya proses belajar mengajar dapat tercipta dengan baik.

Edi Sunarti yang dikutip oleh Sardiman (2009 : 15-17) mengatakan Ciriciri interaksi belajar mengajar sebagai berikut :

1. Interaksi belajar mengajar memiliki tujuan, yakni untuk membantu anak tidak dalam suatu perkembangan tertentu.

Inilah yang dimaksud interaksi belajar mengajar itu sadar tujuan, dengan 
menempatkan siswa sebagai pusat perhatian.

2. Ada suatu prosedur (jalannya interaksi) yang direncanakan, didesain untuk mencapai tujuan yang telah ditetapkan

Agar dapat mencapai tujuan secara optimal, maka dalam melakukan interaksi perlu adanya prosedur atau langkahlangkah sistematis dan relevan.

3. Interaksi belajar mengajar ditandai dengan satu penggarapan materi khusus

Dalam hal ini materi harus didesain sedemikian rupa sehingga cocok untuk mencapai tujuan. Sudah barang tentu dalam hal ini perlu diperhatikan komponen-komponen yang lain, apalagi komponen anak didik yang merupakan sentral. Materi harus sudah didesain dan disiapkan sebelum berlangsungnya interaksi belajar mengajar.

4. Ditandai dengan adanya aktivitas siswa Sebagai konsekuensi, bahwa siswa merupakan sentral, maka aktivitas siswa merupakan syarat mutlak bagi berlangsungnya interaksi belajar mengajar. Aktivitas siswa dalam hal ini, baik secara fisik maupun secara mental aktif.

5. Dalam interaksi belajar mengajar, guru berperan sebagai pembimbing

Dalam perannya sebagai pemimbing ini,guru harus berusaha menghidupkan dan memberikan motivasi agar terjadi proses interaksi yang kondusif. Guru harus siap sebagai mediator dalam segala situasi proses belajar mengajar, sehingga guru akan merupakan tokoh yang akan dilihat dan ditiru tingkah lakunya oleh anak didik.

6. Di dalam interaksi belajar mengajar dibutuhkan disiplin

Disiplin dalam interaksi belajar mengajar ini diartikan sebagai suatu pola tingkah laku yang diatur sedemikian rupa menurut ketentuan yang sudah ditaati oleh semua pihak dengan secara sadar, baik pihak guru maupun pihak siswa.

7. Ada batas waktu

Untuk mencapai tujuan pembelajaran tertentu dalam sistem berkelas (kelompok siswa), batas waktu merupakan ciri yang tidak bisa ditinggalkan. Setiap tujuan akan diberi waktu tertentu, kapan tujuan itu harus sudah dicapai.

Berdasarkan kutipan di atas, penulis mengambil kesimpulan bahwa ciri-ciri interasksi belajar mengajar, yaitu harus memiliki tujuan, memiliki prosedur, adanya bahan, adanya guru, adanya aktivitas siswa, batas waktu, harus disiplin. Dan dengan ciriciri tersebut maka akan tercipta interaksi belajar mengajar yang baik.

Berdasarkan hasil penelitian tentang Peranan Guru PAK sebagai Komunikator dalam Meningkatkan Komunikasi yang Efektif kepada Siswa Kelas XI SMK Negeri 1 Siatas Barita Kabupaten Tapanuli Utara Tahun Pembelajaran 2017/2018 diperoleh hasil analisis dan menunjukkan secara umum bahwa Guru PAK berperan baik sebagai komunikator dalam meningkatkan komunikasi yang efektif kepada siswa kelas XI SMK Negeri 1 Siatas Barita Kabupaten Tapanuli Utara Tahun Pembelajaran 2017/2018. Namun dari hasil data tersebut terdapat item yang menunjukkan nilai ratarata pada kategori yang kurang baik yakni Item no. 12. Pada saat proses belajar mengajar berlangsung, apakah guru PAK saudara menggunakan media dalam menyampaikan materi pelajaran ? Termasuk kategori kurang baik dengan nilai rata-rata 2,45 .

Dari hasil analisa data maka dapat dilihat bahwa Peranan Guru PAK sebagai Komunikator dalam Meningkatkan Komunikasi yang Efektif kepada Siswa Kelas XI SMK Negeri 1 Siatas Barita Kabupaten Tapanuli Utara Tahun Pembelajaran 2017/2018 adalah baik. Hal ini diperoleh dari seluruh indikator yang 
diteliti diperoleh hasil bahwa Guru PAK berperan baik sebagai komunikator dalam meningkatkan komunikasi yang efektif.

Dengan demikian hipotesa penelitian tentang Peranan Guru PAK sebagai Komunikator dalam Meningkatkan Komunikasi yang Efektif kepada Siswa Kelas XI SMK Negeri 1 Siatas Barita Kabupaten Tapanuli Utara Tahun Pembelajaran 2017/2018 adalah diterima. Hal ini diperoleh dari aspek yang diteliti yaitu aspek Peranan Guru PAK sebagai Komunikator dalam Meningkatkan Komunikasi yang Efektif kepada Siswa Kelas XI SMK Negeri 1 Siatas Barita Kabupaten Tapanuli Utara Tahun Pembelajaran 2017/2018 termasuk kategori baik dengan nilai rata-rata 3,29 yang berada pada kategori baik.

\section{SIMPULAN}

1. Kesimpulan Teoritis

a. Guru PAK sebagai komunikator dalam meningkatkan komunikasi yang efektif sebaiknya memberi penilaian atas kemajuan peserta didik, sebagai komentator, sebagai mediator, memberikan waktunya untuk mewujudkan perdamaian, mengutamakan pemberian berita dari segi kebutuhan pendengarnya, mengerti tingkat kesiapan anak didiknya ketika mendengarkan pesan yang disampaikan.

b. Guru PAK sebagai komunikator dalam meningkatkan komunikasi yang efektif memiliki peranan yang besar terhadap siswa, karena guru PAK harus mengajak siswa untuk saling berkomunikasi supaya proses belajar mengajar tidak pasif dan berjalan dengan baik.

c. Di dalam melakukan komunikasi di dalam proses belajar mengajar hendaknya guru PAK memperhatikan bentuk komunikasi yang hendak dilakukan dan disesuaikan dengan situasi materi pelajaran yang akan dilaksanakan agar tercipta tujuan pembelajaran yang hendak dicapai.

2. Kesimpulan Hasil Penelitian

Berdasarkan hasil penelitian tentang Peranan Guru PAK sebagai Komunikator dalam Meningkatkan Komunikasi yang Efektif kepada Siswa Kelas XI SMK Negeri 1 Siatas Barita Kabupaten Tapanuli Utara Tahun Pembelajaran 2017/2018 diperoleh hasil analisis data menunjukkan secara umum bahwa Guru PAK berperan baik dalam meningkatkan komunikasi yang efektif kepada siswa. Hal ini diperoleh dari aspek yang diteliti yaitu aspek Peranan Guru PAK sebagai Komunikator dalam Meningkatkan Komunikasi yang Efektif kepada Siswa Kelas XI SMK Negeri 1 Siatas Barita Kabupaten Tapanuli Utara Tahun Pembelajaran 2017/2018 termasuk kategori baik dengan nilai rata-rata 3, 29 yang berada pada kategori baik.

3. Kesimpulan Akhir

Berdasarkan kesimpulan teori dan kesimpulan penelitian tentang Peranan Guru PAK sebagai Komunikator dalam Meningkatkan Komunikasi yang Efektif kepada Siswa Kelas XI SMK Negeri 1 Siatas Barita Kabupaten Tapanuli Utara Tahun Pembelajaran 2017/2018 diperoleh hasil bahwa Guru PAK berperan baik dalam meningkatkan komunikasi yang efektif.

\section{DAFTAR PUSTAKA}

[1] Achmadi. (2004). Metodologi Penelitian. Jakarta: Bumi Aksara

[2] Arikunto. (1989). Prosedur Penelitian. Jakarta: Rineka Cipta

[3] (2007). Manajemen Penelitian. Jakarta: Rineka Cipta

[4] Cangara, H. (2005). Pengantar Ilmu Komunikasi. Jakarta: PT Raja Grafindo Persada.

[5] Djamarah, S. B. (2000). Guru dan Anak Didik Dalam Interaksi Edukatif. Jakarta: Rineka Cipta. 
[6] Effendy, O. U. (1990). Ilmu Komunikasi Teori dan Praktek. Bandung: PT Raja Grafindo Persada.

[7] Gunarsa, S. (2003). Psikologi Remaja. Jakarta: BPK Gunung Mulia.

[8] Kristianto, L. P. (2006). Prinsip dan Praktek PAK. Yogyakarta: ANDI

[9] LAI. Alkitab.

[10] Mulyana, D. (2007). Ilmu Komunikasi Suatu Pengantar. Bandung: PT Raja Grafindo Persada.

[11] Manullang, M. (2004). Pedoman Teknis Menyusun Skipsi. Yogyakarta: ANDI.

[12] Nasution, S. (1987). Metode Reseach. Jakarta: Gramedia Pustaka Umum.

[13] Nurkanca. (1986). Evaluasi Pendidikan. Surabaya: Usaha Nasional.

[14] Rakhmat, J. (2005). Psikologi Komunikasi. Bandung: PT Raja Grafindo Persada.

[15] Sardiman. (2009). Interaksi dan Motivasi Belajar Mengajar. Jakarta: Raja Grafindo Persada.

[16] Siahaan, S. M. (1991). Komunikasi : Pemahaman dan Penerapannya. Bandung: PT Raja Grafindo Persada.

[17] Sidjabat, B. S. (2009). Mengajar Secara Profesional : Mewujudkan Visi Guru Profesional. Bandung: Yayasan Kalam Hidup.

[18] Seokanto, S. (2004). Sosiologi Suatu Pengantar. Jakarta: PT Raja Grafindo Persada.

[19] Sumanto. (1990). Metodologi Penelitian Sosial dan Pendidikan. Yogyakarta: ANDI.

[20] Sumiyatiningsih, D. (2006). Mengajar Dengan Kreatif dan Menarik. Yogyakarta: ANDI.

[21] Wursanto. (1987). Etika Komunikasi Kantor. Yogyakarta: Kanisius. 